PSICOLOGÍA

IBEROAMERICANA
Psicología Iberoamericana ISSN: 1405-0943

revista.psicologia@ibero.mx

Universidad Iberoamericana, Ciudad de México México

\title{
Women, domestic labour and COVID-19: Exploring the inequitable gendered impacts of COVID - 19
}

\section{Gordon, Sarah Frances}

Women, domestic labour and COVID-19: Exploring the inequitable gendered impacts of COVID - 19

Psicología Iberoamericana, vol. 29, núm. 1, 2021

Universidad Iberoamericana, Ciudad de México, México

Disponible en: https://www.redalyc.org/articulo.oa?id=133967526006

DOI: https://doi.org/10.48102/pi.v29i1.406

Los autores/as conservan los derechos de autor y ceden a la revista el derecho de la primera publicación, con la obra registrada bajo la Licencia Creative Commons Atribución 4.0 Internacional.

Los autores/as conservan los derechos de autor y ceden a la revista el derecho de la primera publicación, con la obra registrada bajo la Licencia Creative Commons Atribución 4.0 Internacional.

\section{(c) (i)}

Esta obra está bajo una Licencia Creative Commons Atribución 4.0 Internacional. 


\title{
Editorial
}

\section{Women, domestic labour and COVID-19: Exploring the inequitable gendered impacts of COVID - 19}

\author{
Mujeres, trabajo doméstico y COVID-19: explorando \\ el incremento en la desigualdad de género causada por la \\ COVID-19 \\ Sarah Frances Gordon sarah.gordon@ibero.mx \\ Universidad Iberoamericana, Mexico City, México \\ https://orcid.org/0000-0001-5131-8519
}

Psicología Iberoamericana, vol. 29, núm. 1,2021

Universidad Iberoamericana, Ciudad de México, México

DOI: https://doi.org/10.48102/ pi.v29i1.406

Redalyc: https://www.redalyc.org/ articulo.oa?id=133967526006
COVID-19 was officially declared a pandemic in March 2020 by the World Health Organisation (2020) and has changed the way we live and work, causing a cascade of political, economic and social breakdowns (Kisner, 2021). The pandemic has shone a light on gender inequalities in unpaid labour in Mexico with women being expected to be responsible for increased household chores, childcare, assisting their children with online classes, as well as caring for the elderly and family members sick with COVID-19 (Manrique De Lara \& De Jesús Medina Arellano, 2020; Observatorio de Género y COVID-19, 2021). In particular, the unpaid care work involved in caring for elderly family members in Mexico is an important issue, especially since research indicates that the number of dependent older adults in Mexico is more than 2 million people (around $2 \%$ of the population) and if demographic trends remain the same, this number could rise to more than 8 million by 2050 (Aranco et al., 2018; Ortega \& Aranco, 2019). Despite this, unpaid care work and domestic labour, which involves caring for children, elderly or sick family members and the general maintenance of the household are greatly underestimated in society and often exploited.

Globally, more than $75 \%$ of unpaid care and domestic work is done by women and young girls (International Labour Office, 2018), and in Mexico, this statistic is $74.3 \%$ (Charmes, 2019). Before the pandemic, women in Mexico dedicated an average of 29 hours a week to unpaid care work and domestic labour, whilst men only dedicated 9.2 hours a week (Charmes, 2019). It is safe to assume that this number has gone up significantly since the pandemic. Recent research also shows that globally, young girls spend significantly more hours on household chores compared to boys, and school closures during the COVID-19 pandemics means that now young girls are taking on more chores at home (United Nations, 2020). 
In Mexico, unpaid care work and domestic labour have been historically and culturally assigned to women (Amilpas García, 2020) and women are often expected to care for children and elderly relatives without any recognition or payment. Research shows that the impact of this type of unpaid labour is enormous and compensates for a lack of public expenditure on care services and infrastructure (International Labour Office, 2018). However, the domestic labour of women is ignored in society and instead, women's empowerment is measured by their presence in the workplace, which is attained by outsourcing housework and childcare to others, usually women of lower socioeconomic status (Kisner, 2021). The devaluation of domestic labour in the home is not accidental as this devaluation further entrenches the patriarchal ideas underpinning many societies. Additionally, the inequitable division of unpaid care work, with the majority of the burden falling to women, is aligned with socially constructed gender norms that define women as "nurturing, self-sacrificing, and caring- and men as breadwinners" (King et al., 2020, p. 80).

The unequal distribution of unpaid care work also represents a barrier to women as it hinders their participation in the workforce and limits their ability to support themselves, especially now during the COVID-19 pandemic (International Labour Office, 2018; King et al., 2020; Sullivan, 2019). For example, in 2020, 2.3 million women in the U.S. dropped out of the workforce, often to care for their children as schools closed due to the pandemic (Kisner, 2021). During this crisis, women are more likely to withdraw from the workforce if their workplace does not offer flexible hours or they do not have support from their partner or family members.

These revelations surrounding the gender inequalities of the pandemic have given rise to more research on the matter. Xue and McMunn's (2021) recent quantitative study on gender differences in unpaid care work and psychological distress during the UK Covid-19 lockdown, using a nationally representative sample from the UK, found that women spent more time on unpaid care work than men during the Coronavirus pandemic and that it was more likely to be the mother than the father who reduced her working hours to increase time on childcare and assist with online classes. As a result, the women in the study were more likely to report increased levels of psychological distress (Xue \& McMunn, 2021). This study is just one example of the research being done on this issue. A substantial amount of literature and research has been published recently on the inequitable gendered impacts of COVID - 19 in different countries, such as South Africa (Parry \& Gordon, 2021), the US (Bahn et al., 2020; Raile et al.,, 2020), Israel (Kristal \& Yaish, 2020), Germany (Czymara et al., 2021; Power, 2020), the UK (Fisher \& Ryan, 2021; Oreffice \& Quintana-Domeque, 2021; Xue \& McMunn, 2021), Spain (Farre et al., 2020), the European region (Cook \& Grimshaw, 2021), Vietnam (Dang \& Viet Nguyen, 2021), and Mexico (Amilpas García, 2020; Manrique De Lara \& De Jesús Medina Arellano, 2020). However, more research should be encouraged in this field, especially in Mexico. 
The COVID-19 pandemic has made it apparent that the world's formal economy and the maintenance of our daily lives are built on the invisible and unpaid labour of women and young girls (United Nations, 2020). The value of women's paid and unpaid labour is becoming increasingly apparent as schools have closed and parents are scrambling to care for their children and other family members whilst maintaining their full-time jobs (Bahn et al., 2020). At the same time, workers who are deemed essential and cannot telecommute are forced to go to work and put themselves and subsequently their families at risk of infection. The COVID-19 crisis has also intensified the care needs of older persons and ill family members, with women often being expected to care for family members sick with COVID-19. The truth is that the unpaid care work and domestic labour performed by women is critical for sustaining our society and policies need to take this into account (United Nations, 2020).

It is evident that the pandemic is deepening pre-existing gender inequalities. As researchers and women, we must begin to contemplate the inequitable gendered impacts of COVID - 19 and think of a way forward. This begins first by acknowledging the valuable contributions of women during this pandemic and then pushing for structural change. Moving forward, new economic policy should be constructed within a broader, feminist framework of human wellbeing and justice (Bahn et al., 2020). There needs to be a transformation of gendered economic discriminations, especially surrounding the inequities of unpaid care work and domestic labour (United Nations, 2020). Specifically, in the case of COVID-19 related policies, women should have equal representation and participation (United Nations, 2020), and countries need to recognise that unpaid care work and domestic labour are important pillars of society. Furthermore, countries, such as Mexico need to develop national care strategies that reduce the burden of care work on women (Observatorio de Género y COVID-19, 2021) and public policies that support work-life balance should be adopted (Amilpas García, 2020).

\section{References}

Amilpas García, M. (2020). Mujeres, trabajo de cuidados y sobreexplotación desigualdades de género en México durante la pandemia por COVID-19. Revista Espacio I+D Innovación Más Desarrollo, 9(25), 99-117. https://d oi.org/10.31644/imasd.25.2020.a06

Aranco, N., Stampini, M., Ibarrarán, P., \& Medellín, N. (2018). Panorama de envejecimiento y dependencia en América Latina y el Caribe. Banco Interamericano de Desarrollo. http://dx.doi.org/10.18235/0000984

Bahn, K., Cohen, J., \& Meulen Rodgers, Y. (2020). A feminist perspective on COVID - 19 and the value of care work globally. Gender, Work \& Organization, 27(5), 695-699. https://doi.org/10.1111/gwao.12459

Charmes, J. (2019). The unpaid care work and the labour market: An analysis of time use data based on the latest world compilation of time-use surveys. 
International Labour Organization. https://www.ilo.org/global/publicat ions/lang--en/index.htm

Cook, R., \& Grimshaw, D. (2021). A gendered lens on COVID-19 employment and social policies in Europe. European Societies, 23(sup1), S215-S227. h ttps://doi.org/10.1080/14616696.2020.1822538

Czymara, C. S., Langenkamp, A., \& Cano, T. (2021). Cause for concerns: Gender inequality in experiencing the COVID-19 lockdown in Germany. European Societies, 23(sup1), S68-S81. https://doi.org/10.1080/146166 96.2020 .1808692

Dang, H. A. H., \& Viet Nguyen, C. (2021). Gender inequality during the COVID-19 pandemic: Income, expenditure, savings, and job loss. World Development, 140, 105296. https://doi.org/10.1016/j.worlddev.2020.10 5296

Farre, L., Fawaz, Y., Gonzalez, L., \& Graves, J. (2020). How the Covid-19 lockdown affected gender inequality in paid and unpaid work in Spain (No. IZA Discussion Paper No. 13434). https://papers.ssrn.com/abstract=36 43198

Fisher, A. N., \& Ryan, M. K. (2021). Gender inequalities during COVID-19. Group Processes \& Intergroup Relations, 24(2), 237-245. https://doi.org/ $10.1177 / 1368430220984248$

International Labour Office. (2018). Care work and care jobs for the future of decent work. International Labour Office.

King, T., Hewitt, B., Crammond, B., Sutherland, G., Maheen, H., \& Kavanagh, A. (2020). Reordering gender systems: Can COVID-19 lead to improved gender equality and health? The Lancet, 396(10244), 80-81. https://doi. org/10.1016/S0140-6736(20)31418-5

Kisner, J. (2021). The lockdown showed how the economy exploits women. She already knew. The New York Times. https://www.nytimes.com/2021/02/17/magazine/waged-house work.html?fbclid=IwAR0DPZLW momC5zBAkGhke8TyaZgE-gFgC3 NnHAgkGXwC5H_JeW8n7v5J0u8

Kristal, T., \& Yaish, M. (2020). Does the coronavirus pandemic level the gender inequality curve? (It doesn't). Research in Social Stratification and Mobility, 68, 100520. https://doi.org/10.1016/j.rssm.2020.100520

Manrique De Lara, A., \& De Jesús Medina Arellano, M. (2020). The COVID-19 pandemic and ethics in Mexico through a gender lens. Journal of Bioethical Inquiry, 17(4), 613-617. https://doi.org/10.1007/s11673-020-10029-4

Observatorio de Género y COVID-19. (2021). Cuidados - Género y Covid. htt ps://genero-covid19.gire.org.mx/tema/trabajo-de-cuidados/

Oreffice, S., \& Quintana-Domeque, C. (2021). Gender inequality in COVID-19 times: Evidence from UK prolific participants. Journal of Demographic Economics, 1-27. https://doi.org/10.1017/dem.2021.2

Ortega, M. L., \& Aranco, N. (2019). Envejecimiento y atención a la dependencia en México (Nota Técnica No IDB-TN-161). Banco Interamericano de Desarrollo. https://publications.iadb.org/publications/spanish/docume nt/Envejecimiento_y_atención_a_la_dependencia_en_México_es.pdf

Parry, B. R., \& Gordon, E. (2021). The shadow pandemic: Inequitable gendered impacts of COVID - 19 in South Africa. Gender, Work \& Organization, 28(2), 795-806. https://doi.org/10.1111/gwao.12565 
Power, K. (2020). The COVID-19 pandemic has increased the care burden of women and families. Sustainability: Science, Practice, and Policy, 16(1), 67-73. https://doi.org/10.1080/15487733.2020.1776561

Raile, A. N. W., Raile, E. D., Parker, D. C. W., Shanahan, E. A., \& Haines, P. (2020). Women and the weight of a pandemic: A survey of four Western US states early in the coronavirus outbreak. Gender, Work \& Organization, 1-12. https://doi.org/10.1111/gwao.12590

Sullivan, O. (2019). Gender inequality in work-family balance. Nature Human Behaviour, 3(3), 201-203. https://doi.org/10.1038/s41562-019-0536-3

United Nations. (2020). Policy brief: The impact of COVID-19 on women. United Nations. https://www.un.org/development/desa/dpad/

World Health Organization (WHO). (2020). WHO Director-General's opening remarks at the media briefing on COVID-19 - 11 March 2020. https://www.who.int/dg/speeches/detail/who-director-general-sopening-remarks-at-the-media-briefing-on-covid-19---11-march-2020

Xue, B., \& McMunn, A. (2021). Gender differences in unpaid care work and psychological distress in the UK Covid-19 lockdown. PLOS ONE, 16(3), e0247959. https://doi.org/10.1371/journal.pone.0247959 